\title{
Biopsy of Jejunum
}

National Cancer Institute

\section{Source}

National Cancer Institute. Biopsy of Jejunum. NCI Thesaurus. Code C51902.

Removal of tissue from the jujunum for microscopic examination, using an endoscope. 